\section{Flower Color, Color Stability, and Flower Longevity in Red-flowered Elepidote Rhododendrons}

\author{
Jessica D. Lubell ${ }^{1}$ and Mark H. Brand
}

ADDITIONAL INDEX WORDS. cold hardiness, cultivar, color-difference formula

SUMMARY. Red-flowered elepidote rhododendrons (Rhododendron sp.) are favored by consumers, but cold-hardy red-flowered rhododendrons frequently have bluered flower hue rather than the preferred red flower hue. Flower longevity, color, and color stability over 14 days were studied for the following eight elepidote rhododendron cultivars possessing red flowers: Besse Howells, Burma, Cary's Red, Firestorm, Francesca, Henry's Red, Low Red Frilled, and Nova Zembla. The eight cultivars were separated by flower hue into two distinct groups of four cultivars each. Rhododendron cultivars Burma, Firestorm, Francesca, and Henry's Red produced flowers with red hue and Besse Howells, Cary's Red, Low Red Frilled, and Nova Zembla produced flowers with blue-red hue. Flower longevity among rhododendron cultivars varied with Francesca blooms lasting the longest at over 14 days, and Besse Howells and Firestorm blooms lasting the shortest at $\approx 10$ days. As flowers aged, hue angle decreased (became bluer), lightness increased, and chroma decreased or remained unchanged. The degree of change in flower color over time differed among cultivars, with 'Francesca' demonstrating the least change $\left(\Delta E_{00} \approx 3\right)$ and 'Besse Howells' the most change $\left(\Delta E_{00} \approx 11\right)$.

$\mathrm{E}$ lepidote rhododendrons are important landscape plants because of showy flowers and bold evergreen foliage. The most common flower colors are lavender, pink, and white, but red flower color is highly sought after. Only some elepidote rhododendrons possess sufficient cold hardiness to survive in the colder parts of the northern United States. These very cold-hardy rhododendrons that are able to withstand severe winter conditions are often referred to as "iron-clads." The American Rhododendron Society categorizes rhododendron cold hardiness in groups from $\mathrm{Hl}$ to $\mathrm{H} 6$, with $\mathrm{Hl}$ being the hardiest and $\mathrm{H} 6$ being the least cold-hardy. Flower buds of $\mathrm{Hl}$ plants can tolerate cold temperatures down to around minus $25^{\circ} \mathrm{F}$ (Kelley, 1991).

$\mathrm{Hl}$ elepidote rhododendrons with red flower color are not that numerous. Many of the red elepidote rhododendrons that have exhibited good cold hardiness over time have been faulted for having red flower color that is contaminated with blue (Brand and Mehlquist, 1992). Often

Department of Plant Science and Landscape Architecture, University of Connecticut, Storrs, CT 06269.

${ }^{1}$ Corresponding author. E-mail: Jessica.lubell@ uconn.edu.

doi: 10.21273/HORTTECH03792-17 the desire is to have ornamental plants with truer red color (Behe et al., 1997, 1999). One objective of this study was to evaluate flower color among $\mathrm{Hl}$ category, red-flowering rhododendron cultivars to identify those cultivars that produce the reddest flowers and those cultivars that are blue-red in color. Another issue with many red-flowered rhododendrons is that the flower color tends to fade and bleach, especially under full sun exposure. Studies documenting how red rhododendron flower color changes over time have not been reported. Therefore, another objective was to examine the rate and degree of flower color change over time from the start of flowering to the end of flowering.

\section{Materials and methods}

Three plants each of the rhododendron cultivars, Besse Howells, Burma, Cary's Red, Firestorm, Francesca, Henry's Red, Low Red Frilled, and Nova Zembla (Table 1) were obtained from nurseries and potted into trade no. 3 containers using a growth medium composed of four parts of aged pine bark (Fafard, Agawam, MA), two parts of Canadian peatmoss (Fafard) and one part of sand. Plants were overwintered in an unheated polyethylene-covered metal hoop house. Overwintered plants were brought into a greenhouse with set points of $21{ }^{\circ} \mathrm{C}$ day and $17^{\circ} \mathrm{C}$ night for forcing on the first day of May. Plants were arranged on greenhouse benches in a randomized complete block design with three replications. Depending on the cultivar, flowering started between 21 and 30 May and ended between 2 June and 15 June, and the number of days that plants were in flower was recorded for each plant. For five flower trusses per plant a single petal, located left or right of the dorsal petal containing the flare, was selected and its color was analyzed every day during the flowering period using a colorimeter (CR-400 Chroma Meter; Konica Minolta Sensing Americas, Ramsey, NJ) connected to a data processor (DP-400; Konica Minolta Sensing Americas). Commission Internationale de l'Eclairage (CIELAB, Vienna, Austria) measurements, lightness $\left(L^{*}\right)$, red-green axis $\left(a^{*}\right)$, and blue-green axis $\left(b^{*}\right)$, were taken per petal and these values were averaged for each plant. The colorimeter was calibrated at illuminant $\mathrm{C}$ with a white standard. Because of the slightly translucent nature of the plant petal tissue, a standard white background was placed behind each leaf when a CIELAB measurement was taken (Little, 1964). In addition to the CIELAB coordinated value, $L^{*}$, the coordinates of hue angle $\left(\tan -1 b^{*} / a^{*}\right)$, and chroma $\left(a^{*} 2+\right.$ $\left.b^{\star} 2\right)$ were calculated from $a^{*}$ and $b^{*}$. Red hues occur on both sides of the $0^{\circ}$ and $360^{\circ}$ interface on the CIELAB hue wheel. To make values continuous across the hue angles that comprise red hues, $360^{\circ}$ was added to hue angles from $0^{\circ}$ to $20^{\circ}$. Color difference $\left(\Delta E_{00}\right)$ from day 1 to day 10 was calculated for all cultivars using the CIEDE2000 color-difference formula (Sharma et al., 2005). Flowering longevity and flower color-difference

\begin{tabular}{llll}
\hline $\begin{array}{l}\text { Units } \\
\text { To convert U.S. to SI, } \\
\text { multiply by }\end{array}$ & U.S. unit & SI unit & $\begin{array}{l}\text { To convert SI to U.S., } \\
\text { multiply by }\end{array}$ \\
\hline$\left({ }^{\circ} \mathrm{F}-32\right) \div 1.8$ & ${ }^{\circ} \mathrm{F}$ & ${ }^{\circ} \mathrm{C}$ & $\left({ }^{\circ} \mathrm{C} \times 1.8\right)+32$
\end{tabular}


Table 1. Nomenclature, parentage, cold hardiness, bloom time, and plant description of eight red-flowering, elepidote rhododendron cultivars. Plant descriptions are based on observations in Connecticut and literature sources.

\begin{tabular}{|c|c|c|c|c|}
\hline Cultivar & Parentage & $\begin{array}{l}\text { Cold } \\
\text { hardiness } \\
\left({ }^{\circ} \mathbf{F}\right)^{\mathrm{z}}\end{array}$ & Bloom time & Plant description ${ }^{\mathrm{y}}$ \\
\hline Besse Howells & $\begin{array}{l}\text { Red catawba }(R \text {. catawbiense }) \times \\
\text { 'Boule de Neige' }\end{array}$ & At least -20 & Early midseason & $\begin{array}{l}\text { Compact habit; flowers frilly with darker } \\
\text { dorsal blotch and speckling of moderate } \\
\text { impact }\end{array}$ \\
\hline Burma & 'Mars' × 'Fanfare' & -20 & Late midseason & $\begin{array}{l}\text { Broad, rounded habit, relatively compact; } \\
\text { flowers with darker dorsal blotch and } \\
\text { speckling of minimal to moderate impact }\end{array}$ \\
\hline Cary's Red & Unknown $\times$ unknown & -20 & Late midseason & $\begin{array}{l}\text { Upright spreading habit; flowers with } \\
\text { darker dorsal blotch and speckling of } \\
\text { minimal impact }\end{array}$ \\
\hline Firestorm & 'Vulcan' × 'Chocolate Soldier' & -25 & Late season & $\begin{array}{l}\text { Low, compact habit; new leaves lime } \\
\text { green; flowers large with dorsal blotch and } \\
\text { speckling of minimal impact }\end{array}$ \\
\hline Low Red Frilled & $\begin{array}{l}\text { Red catawbiense seedling } \times \\
\text { unknown }\end{array}$ & -25 & Late midseason & $\begin{array}{l}\text { Compact habit; flowers frilly with darker } \\
\text { dorsal blotch and speckling of minimal to } \\
\text { moderate impact }\end{array}$ \\
\hline Nova Zembla & $\begin{array}{l}\text { 'Parson's Grandiflorum' } \times \\
\text { hardy red hybrid }\end{array}$ & -25 & Midseason & $\begin{array}{l}\text { Tall growing, vigorous plant; flowers with } \\
\text { dark dorsal blotch and speckling of } \\
\text { moderate impact }\end{array}$ \\
\hline
\end{tabular}

${ }^{\mathrm{z}}\left({ }^{\circ} \mathrm{F}-32\right) \div 1.8={ }^{\circ} \mathrm{C}$

${ }^{y}$ Information adapted from American Rhododendron Society (1998), Brooks (1999), and Hirsutum (2009).

data were subjected to analysis of variance [ANOVA (PROC GLM)] and mean separation using Tukey's honestly significant difference (HSD) test $(P \leq 0.05)$ using SAS (version 9.4 for Windows; SAS Institute, Cary, NC).

\section{Results and discussion}

There was a difference of about $5 \mathrm{~d}$ between cultivars with the longest bloom time and those with the shortest bloom time (Fig. 1). 'Francesca' rhododendron blooms lasted longest, at over $14 \mathrm{~d}$. 'Nova Zembla' rhododendron and 'Burma' rhododendron blooms lasted as long and were statistically the same as 'Francesca' rhododendron. 'Besse Howells' rhododendron and 'Firestorm' rhododendron flowers had the shortest longevity, at just over 9 d (Fig. 1). 'Cary's Red' rhododendron and 'Henry's Red' rhododendron were statistically no different in flower longevity than 'Besse Howells' rhododendron and 'Firestorm' rhododendron.

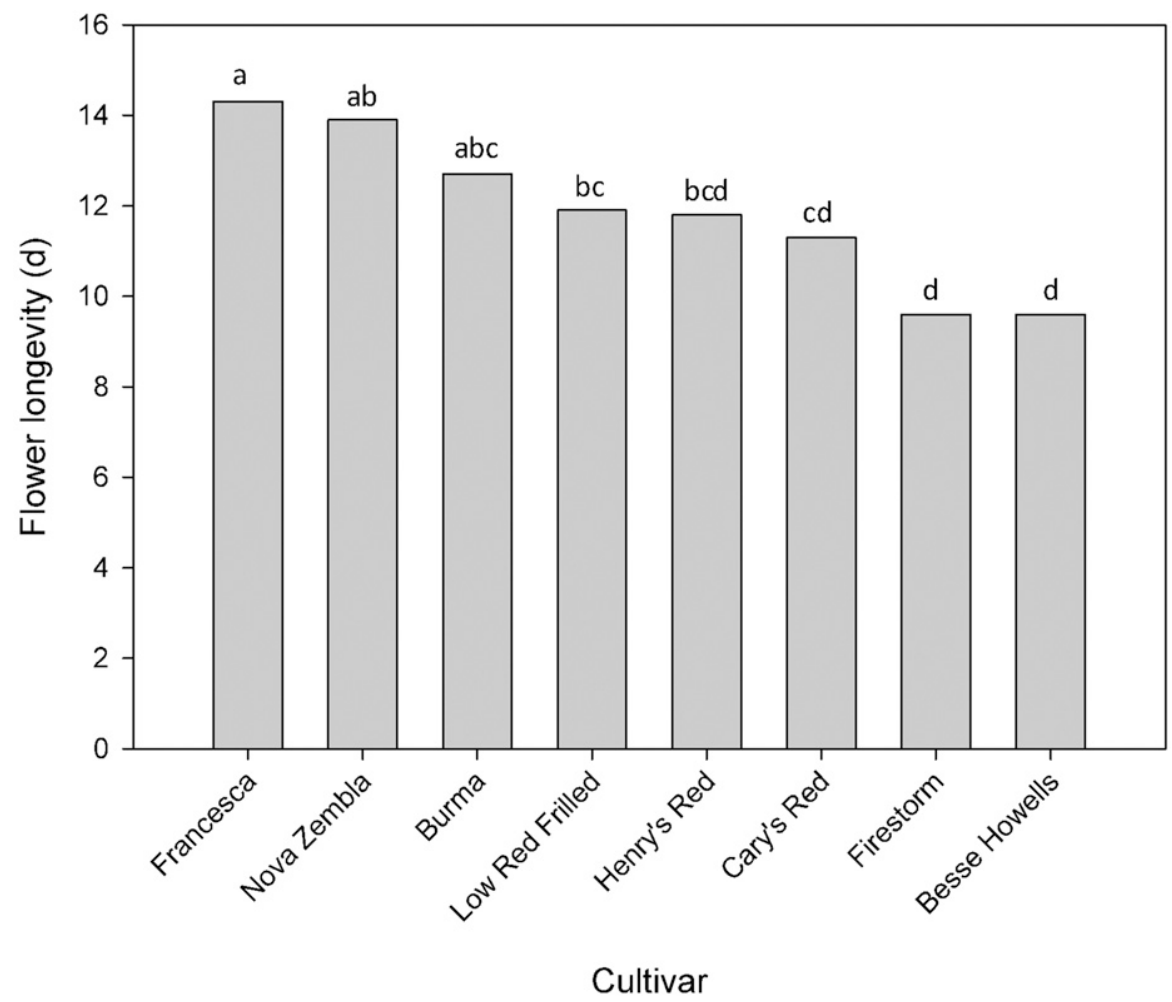

Fig. 1. Flower longevity for eight cultivars of rhododendron. Mean separation by Tukey's honestly significant difference (HSD) test with different letters denoting significance at $P \leq 0.05(n=3)$. 

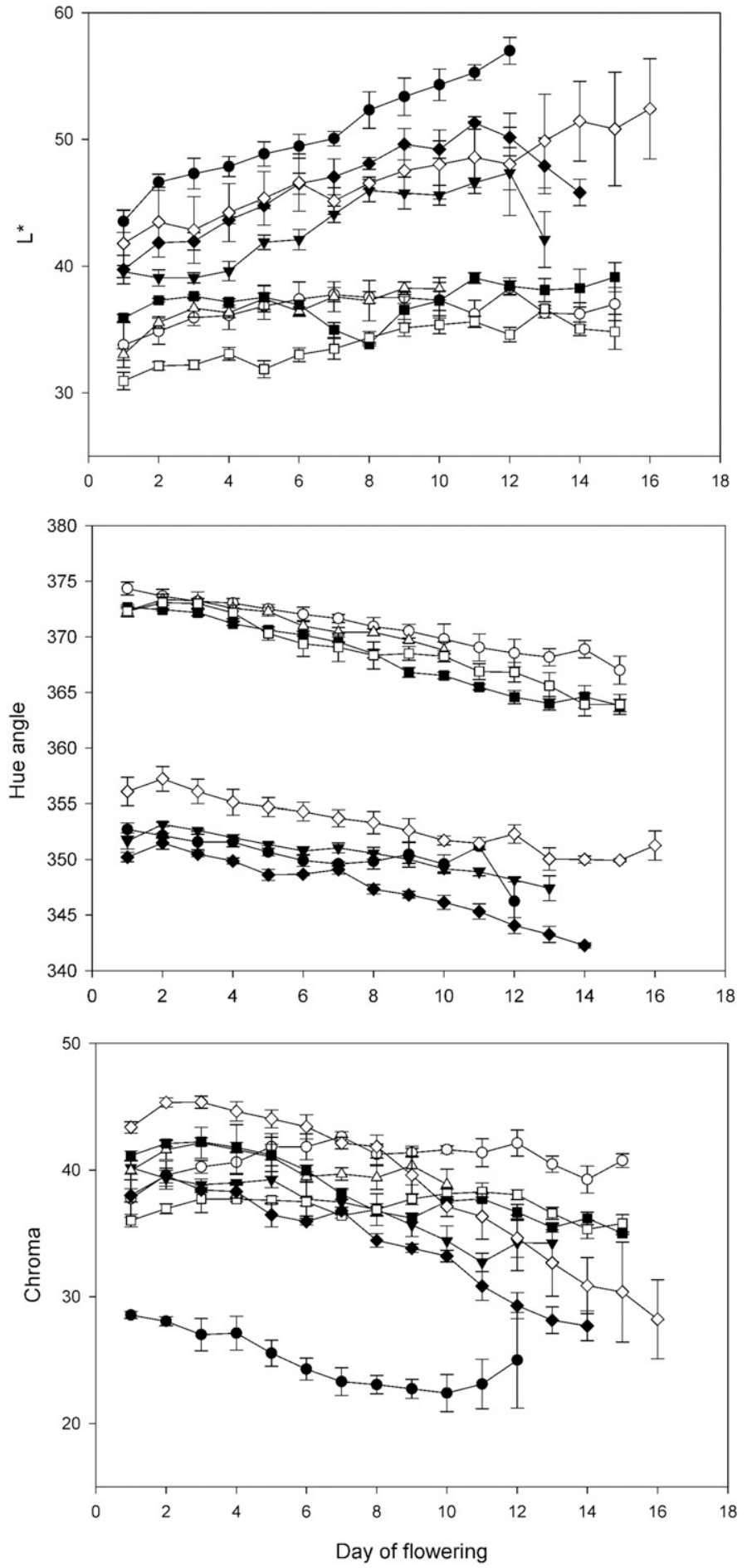

Fig. 2. Floral CIELAB $L^{*}$, hue angle, and chroma for eight cultivars of rhododendron. For hue angles above $360^{\circ}$, subtract $360^{\circ}$ to obtain the true hue angle value. Vertical bars indicate $\pm \operatorname{SE}(n=3)$.

Hue angle for cultivars ranged from around $350^{\circ}$ to close to $15^{\circ}$ for just opened flowers (Fig. 2). Hue angles generally trended downward over time, becoming slightly bluer in hue with the passage of days. For most cultivars, hue angle decreased by $5^{\circ}$ to $10^{\circ}$ from first opening until
Besse Howells, Cary's Red, Low Red Frilled, and Nova Zembla. A second group of four cultivars had hue angles that ranged between $12^{\circ}$ and $15^{\circ}$ for newly opened flowers. These four cultivars would be characterized as having red flowers, lacking substantial blue influence. These included rhododendron cultivars Burma, Firestorm, Francesca, and Henry's Red.

Anthocyanins of the cyanidin and delphinidin series and the flavonol, gossypetin, all contribute to red flower color in rhododendron (Arisumi and Miyajima, 1985). The proportions and compositions of these pigments are responsible for dictating hue (Pecherer, 1992). Cyanidin is responsible for red flower color in rhododendron, and the addition of delphinidin results in blueish red flower color. It is the same for evergreen azalea (Rhododendron), where genotypes with blue-red flowers contain both cyanidin and delphinidin, whereas red-flowered genotypes have only cyanidin (Mizuta et al., 2009). Gossypetin is primarily associated with yellow flower color in rhododendron (Santamour and Pryor, 1973). It can coexist with cyanidin, but not with delphinidin (Arisumi and Miyajima, 1985). For red-flowered rhododendrons, it is likely that cyanidin alone, or in conjunction with gossypetin, results in red hue, and cyanidin and delphinidin in combination produces blue-red hues. In addition to copigmentation of anthocyanins and flavonols, the methylation of flavonols and the hydroxylation of anthocyanins also modify flower color toward bluer hue angles (Arisumi and Miyajima, 1985).

For lightness, as with hue angle, there were two groupings of cultivars (Fig. 2). The same four cultivars that grouped together for hue angle also grouped together for lightness. Cultivars with blue-red flower color had high $L^{*}$ values indicating they had lighter colors than cultivars with red flower color, which had lower $L^{*}$ values. $L^{*}$ values tended to increase over time for many of the cultivars. Flower color for blue-red cultivars lightened more over time than did flower color for red cultivars.

Cultivars did not sort into two distinct groups for chroma as they did 


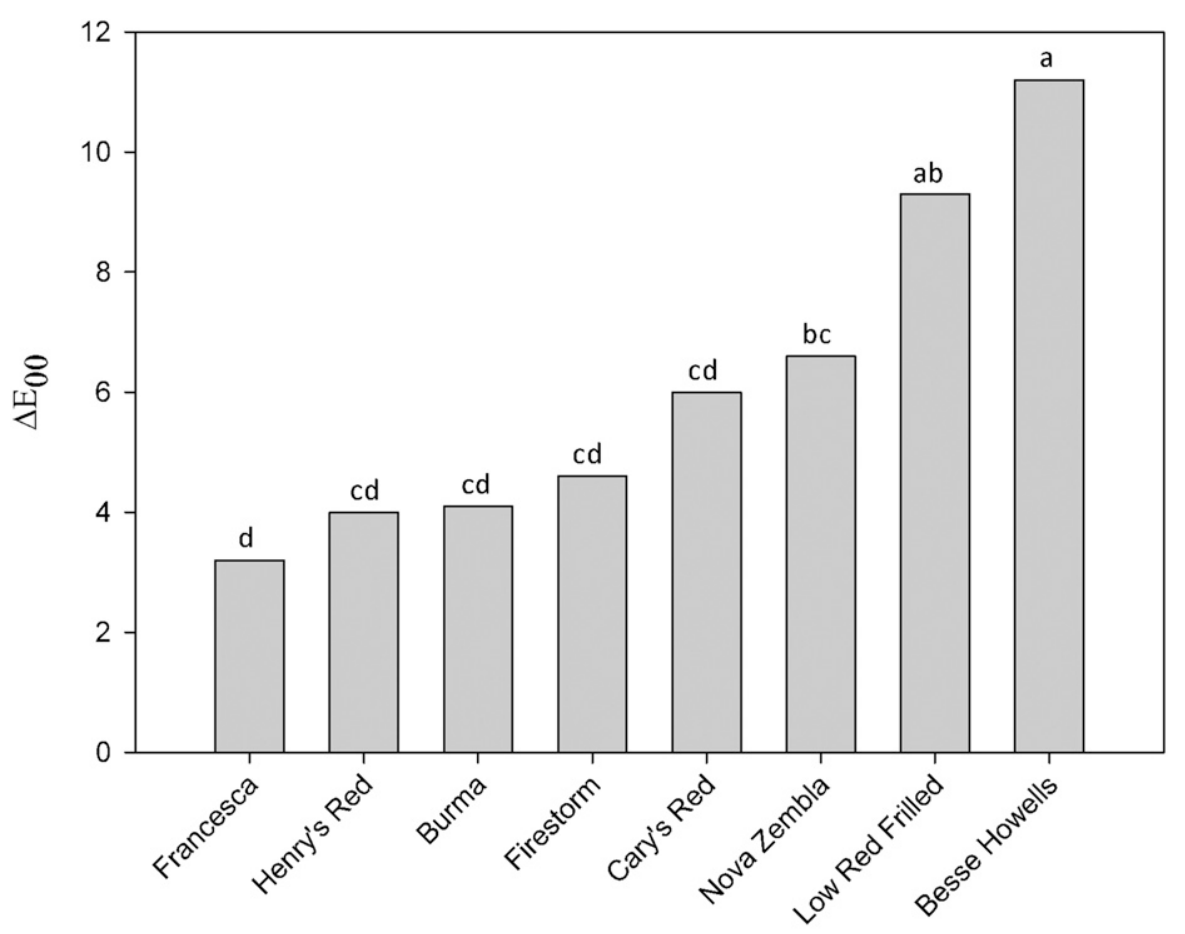

Cultivar

Fig. 3. Flower color difference $\left(\Delta E_{00}\right)$ from day 1 to day 10 of flowering for eight cultivars of rhododendron. Mean separation by Tukey's honestly significant difference (HSD) test with different letters denoting significance at $P \leq 0.05$ $(n=3)$.

for hue angle and lightness (Fig. 2). The majority of cultivars had starting chroma values between 35 and 45 . The one exception was 'Besse Howells' rhododendron, which had significantly lower starting chroma values of around 27 to 28 . For 'Nova Zembla' rhododendron and 'Low Red Frilled' rhododendron chroma values dropped significantly as flowers aged. 'Carey's Red' rhododendron and 'Francesca' rhododendron showed smaller decreases in chroma values. 'Firestorm' rhododendron and 'Henry's Red' rhododendron showed little change in chroma over the life of the flower, whereas 'Burma' rhododendron chroma values actually rose slightly.

'Besse Howells' rhododendron exhibited the greatest change in color difference over time based on CIEDE2000 color-difference calculation (Fig. 3). 'Low Red Frilled' rhododendron also exhibited large color change with flower age. The rhododendron cultivars Francesca, Henry's Red, and Burma exhibited relatively small color changes with aging, with Francesca showing the least change in color over time. Color changes that occurred with flower flower longevity, and resistance to flower color fading or lightening.

\section{Literature cited}

American Rhododendron Society. 1998. Rhododendron plant search options. 10 May 2017. <http://rhododendron.org/ search_intro.asp $>$.

Arisumi, K.Y.S. and I. Miyajima. 1985. Studies on the flower colours in Rhododendron. Mem. Fac. Agr., Kagoshima Univ. 21:133-147.

Behe, B.K., P.B. Redman, and J.M. Dole. 1997. Consumers prefer red poinsettia cultivars. Hort Technology 7:438-441.

Behe, B., R. Nelson, S. Barton, C. Hall, C.D. Safley, and S. Turner. 1999. Consumer preference for geranium flower color, leaf variegation, and price. HortScience 34:740-742.

Brand, M.H. and G.A.L. Mehlquist. 1992. Rhododendron 'Firestorm' and 'White Peter'. HortScience 27:480-481.

Brooks, D. 1999. The Weston hybrids. J. Amer. Rhododendron Soc. 53(4):10 <http://scholar.lib.vt.edu/ejournals / JARS/v53n4/v53n4-brooks.htm>.

Hirsutum. 2009. Rhododendron hybrids/ cultivars. 10 May 2017. <http://hirsutum. info/rhododendron/hybrids/>.

aging are likely the result of pigment degradation (Pecherer, 1992).

\section{Conclusion}

There are many considerations when choosing a red-flowered rhododendron other than the particular color of red flower, including cold hardiness, plant habit, specific bloom time, cultural adaptability, floral composition and structure, and flower blotch or flare. Considerable variation exists in cold-hardy, red elepidote rhododendrons as far as red flower color characteristics are concerned. Consumers wanting red, rather than blue-red rhododendron flowers should choose rhododendron cultivars Francesca, Henry's Red, Firestorm, or Burma. 'Nova Zembla' rhododendron, perhaps the most widely grown and used cold-hardy red elepidote rhododendron, has flowers that are blue-red rather than red. It does exhibit good flower longevity, but its flower color will fade significantly over time. For those seeking a red-flowered elepidote rhododendron, the cultivar Francesca has many positive attributes including non-blue, red flower color, extended
Kelley, J.D. 1991. How to select a rhodie at your local nursery. J. Amer. Rhododendron Soc. 45(3):10 <http://scholar. lib.vt.edu/ejournals/JARS/v45n3/ v45n3-kelley.htm>.

Little, A.C. 1964. Color measurement of translucent food samples. J. Food Sci. 29:782-789.

Mizuta, D., T. Ban, I. Miyajima, A. Nakatsuka, and N. Kobayashi. 2009. Comparison of flower color with anthocyanin composition patterns in evergreen azalea. Sci. Hort. 122:594-602.

Pecherer, B. 1992. The color of rhododendron flowers. J. Amer. Rhododendron Soc. 46(4):1 <http://scholar.lib.vt.edu/ ejournals/JARS/v46n4/v46n4pecherer.htm>.

Santamour, F.S. and R.L. Pryor. 1973. Yellow flower pigments in rhododendron: A review for breeders. J. Amer. Rhododendron Soc. 27(4):1 <http:// scholar.lib.vt.edu/ejournals/JARS / v27n4/v27n4-santamour.htm>.

Sharma, G., W. Wu, and E.N. Dalal. 2005. The CIEDE2000 color-difference formula: Implementation notes, supplementary test data, and mathematical observations. Color Res. Appl. 30:21-30. 